\title{
FEASIBILITY OF INVESTMENT DEVELOPMENT SYUKURAN AMINUDDIN AMIR AIRPORT LUWUK
}

\author{
Hamzah Hasanuddin ${ }^{1)}$, Fahira ${ }^{1)}$, and Nirmalawati1) \\ 1) Civil Engineering Department, Engineering Faculty, Tadulako University, Palu, \\ Indonesia \\ hamzahhasanuddin80@gmail.com
}

\begin{abstract}
Air transport in the town of Luwuk Banggai has increased significantly, this can be seen with increasing volume flight Syukuran Aminuddin Amir Airport average of $17.59 \%$ per year to various regions in the country and has the infrastructure facilities that can accommodate as many as 219261 average passengers/year with a percentage of 17.67\% per year. The results of the research can be used to determine the feasibility of investing in the development of an airport by using economic calculation engineering and value advantage of the extension of the runway to $3000 \mathrm{~m}$ complete with other facilities with competing methods will be applied as follows: Net Present Value (NPV), Benefit-Cost Ratio (BCR), Internal Rate of Return (IRR), and payback period. From the results of investment appraisal using the NPV method results obtained IDR.79,002,433,592.00 with methods derived into $36.142 \%$ IRR greater than $15 \%$ and Profitability Index (PI) has a value of 1.126 that is greater than 1 and analysis Payback Period (PP) was obtained within 15 years to reach the Break-Even Point.
\end{abstract}

Keywords: investment, development, airport

\begin{abstract}
ABSTRAK
Transportasi udara di kota Luwuk Banggai telah meningkat secara signifikan, hal ini dapat dilihat dengan meningkatnya volume penerbangan Bandara Syukuran Aminuddin Amir rata-rata $17.59 \%$ per tahun ke berbagai daerah di tanah air dan memiliki fasilitas infrastruktur yang dapat menampung rata-rata sebanyak 219261 penumpang/tahun dengan persentase $17.67 \%$ per tahun. Hasil penelitian dapat digunakan untuk menentukan kelayakan investasi dalam pengembangan bandara dengan menggunakan teknik perhitungan ekonomi dan nilai keuntungan dari perluasan landasan pacu hingga $3000 \mathrm{~m}$ lengkap dengan fasilitas lain dengan metode bersaing akan diterapkan sebagai berikut: Net Present Value (NPV), Benefit-Cost Ratio (BCR), Internal Rate of Return (IRR), dan periode pengembalian. Dari hasil penilaian investasi dengan menggunakan metode NPV diperoleh hasil Rp.79,002,433,592.00 dengan metode IRR yang didapat menjadi $36.142 \%$ lebih besar dari 15\% dan Profitability Index (PI) memiliki nilai 1.126 yang lebih besar dari 1 dan analisis Payback Period (PP) adalah diperoleh dalam waktu 15 tahun untuk mencapai Break-Even Point.
\end{abstract}

Kata kunci: investasi, pengembangan, bandara 


\section{INTRODUCTION}

The airport was a means of organizing flights in supporting the activities of the region. In addition to having the primary function in supporting inter-regional connectivity, the airport is expected to boost the economic growth of a region. In Indonesia, the construction of airports has a strategic role as a gateway to economic activity, the activity over the mode of transportation, driver of industrial activity and trade, the opening of isolated areas and infrastructure to strengthen the archipelago insight and sovereignty

Luwuk Banggai with a wealth of natural resources such as oil and gas which has managed to attract investors to conduct their business activities in Luwuk Banggai. Contents condition affecting almost all economic and social activity Banggai, particularly airports, which is one mode of transportation that has been chosen by the investor as a mode of transport that promises security, speed and convenience.

Air transport in the town of Luwuk Banggai has increased significantly, this can be seen with increasing volume Aminudin flight on Thanksgiving service Luwuk Amir average of $17.59 \%$ per year to various regions in the country and has the infrastructure facilities that can accommodate as many as 219261 average passengers/year with a percentage of $17.67 \%$ per year. The existence of Syukuran Aminuddin Amir Airport in Banggai has contributed significantly to the economic development of both regional and national territory. The development of the airport facility is considered a strategic transport infrastructure in order to improve the local economy, especially in providing ease of mobility for economic actors and the public.

One of the facilities to be developed is the airside facilities is one of which is an aircraft runway (runway). The expanded facility can be considered an efficient means of mobilization to accommodate service users who steadily. Thanksgiving service with state A. Amir Luwuk long runway is currently not considered to meet safety standards with the correction ARFL long runway for the aircraft type Boeing 737-900, the plans to develop the airport's organizational system airside facilities by increasing the length of the runway from 2250 meters to 3000 meters to be able to serve a larger aircraft type. 


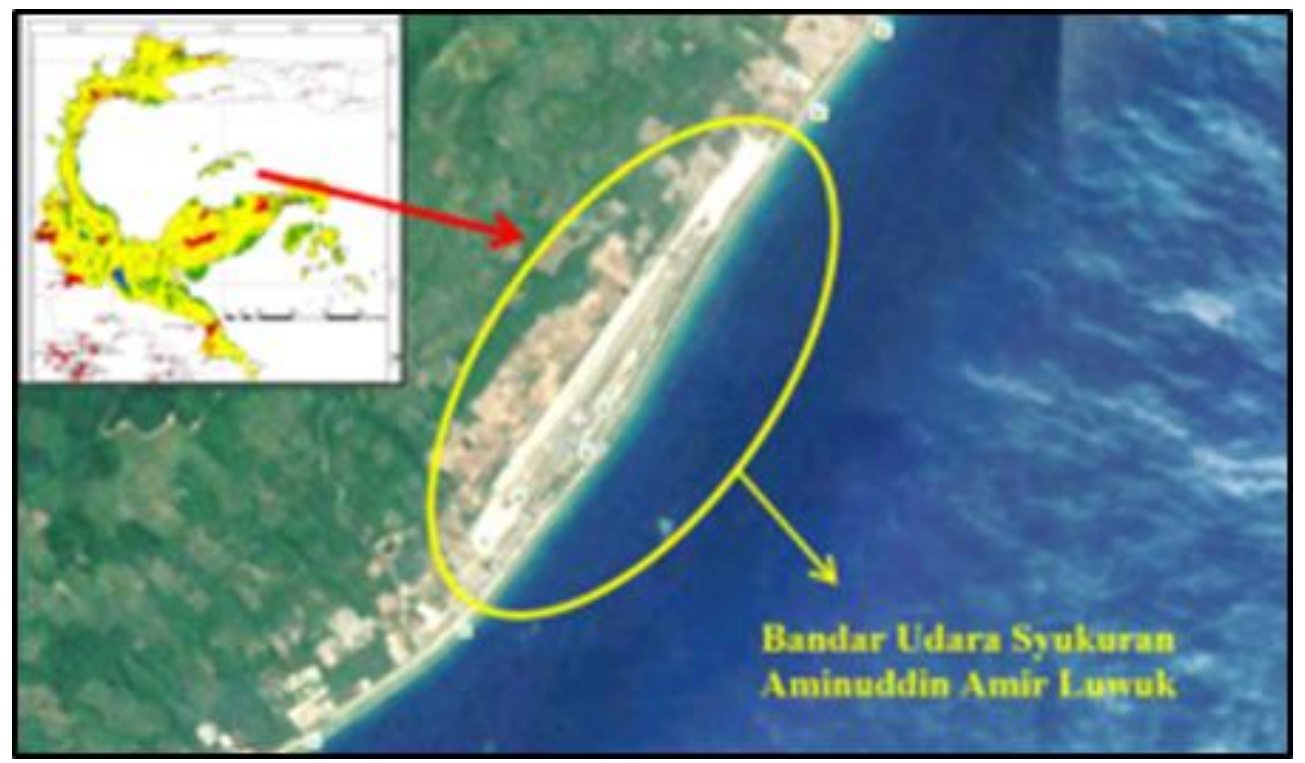

Figure 1. Map Syukuran Aminuddin Amir Airport Luwuk

\section{LITERATURE REVIEW}

\subsection{Net Present Value (NPV)}

NPV method is used to determine the value of the project based on the project's cash flow. Thus the NPV is calculated as the difference between cash flows incurred by the project cash flows received by the project. NPV is reckoned to be the present value using a certain interest rate. Total NPV projects are planned can be calculated with the following formula:

$$
\begin{aligned}
& \mathrm{NPV}=\sum_{\mathbf{t}=\mathbf{0}}^{\mathbf{n}} \frac{\mathbf{C F t}}{(\mathbf{1}+\mathbf{K})} \\
& \mathrm{CFt}=\text { cash flow per year in the } \\
& \mathrm{K}=\text { the interest rate } \\
& \mathrm{t}=\text { year- } \mathrm{t} \\
& \mathrm{n} \quad=\text { life of the project }
\end{aligned}
$$

The rate of capital or the rate of return is very closely related to the level of eligibility for a project whether it will be accepted or rejected. The loss or absence of an investment in a particular project can be seen in the net present value or net present value of the project.

\subsection{Benefit-Cost Ratio (B/C Ratio)}

$\mathrm{B} / \mathrm{C}$ Ratio is comparing the benefits (benefits) obtained at the cost (cost) that have been issued, if the value of the benefits compared to its costs, $>1$ then the economies that have been run, viable, but if the value $<1$, then economics was run less profitable. If obtained is equal to $=1$ means the economics of the run, said marginal (no loss and no profitable), with the following formula:

$$
\mathrm{B} / \mathrm{C} \text { ratio }=\frac{\text { Benefit }}{\text { Cost }}>1
$$




\subsection{Payback Period (PBP)}

PBP is an investment project appraisal based on the repayment of the investment cost of the project or the achievement of the net periodic benefit obtained is equal to the level of investment costs already incurred. PBP is determined by calculating the time it takes for the accumulated cash flow changes from a negative value into a positive value, and benefit from much-needed investments have been equal to the investment cost is formulated as follows:

$$
\mathrm{PBP}=\frac{\% \text { Total Investasi }(100 \%)}{\mathrm{ROI}}
$$

\subsection{Internal Rate of Return (IRR)}

IRR is the interest rate that can make the size of the project NPV equal to zero, or to create B / CR equal to 1 . If IRR < of the interest rate banks can be said that the business is not profitable, and if IRR> of interest can be said that the commodity business is feasible to be developed and can provide benefits, formulated as follows:

$$
\begin{aligned}
& \mathrm{IRR} \rightarrow \sum_{\mathrm{t}=1}^{\mathrm{n}} \frac{\mathrm{Bt}-\mathrm{Ct}}{(1+\mathrm{IRR})}=0 . \\
& \mathrm{Bt}=\text { benefit of all } \mathrm{t} \\
& \mathrm{Ct}=\text { cost of all } \mathrm{t} \\
& \mathrm{t}=\text { year } \\
& \mathrm{n}=\text { life of the project }
\end{aligned}
$$

\subsection{Airport}

The airport is the node for flights which serve the activities of passenger traffic and aircraft, which are used as places of landing and takeoff of aircraft, ups, and downs of passengers, loading and unloading goods, the movement of intermodal transport, which is equipped with safety facilities and aviation security, as well as basic facilities and other supporting facilities. The airport is a particular area of the ground or water (including any buildings, installations, and equipment) intended to be used whole or in part for landing, departure and aircraft movement on the surface. The Aerodrome (airport) can be divided into two parts based on the usefulness of the amenities, airside and the landside. Facilities included in the air is the runway, grounding circuit (taxi's way), and apron.

Aerodrome's airside facilities serve not only as the aircraft took off, but in the air transportation system includes the extensive activities in which there are flows of passengers and goods, including the components included in the system Runway. By its program of infrastructure development, especially the development of the airport runway constituted by observing the movement of air traffic flow for 10 (ten) years. 
Calculation of actual runway length and a power calculation runway closely related to the safety of flight operations and air traffic services are to prevent overrun at the time of landing and prevent failed to take off as well as its relationship to service of air traffic is to limit MTOW (Maximum takeoff Weight) and MLW ( maximum Landing Weight) to prevent damage to the runway at the airport when ACN (aircraft Classification Number) maximum required by the aircraft does not comply with the PCN (Pavement Classification Number).

\subsection{Airport Infrastructure}

The airport construction is a job that requires the availability of large amounts of capital and is complex. Is a capital intensive as the construction of airports require an investment of construction and installation are quite large, on the other hand, the construction of the airport is a very complex because it requires the integration of a variety of occupations and areas of expertise, including the integration intra-modal and inter-modal integration transport within the coverage area served. Therefore, the construction and development of an airport require careful planning so that investment can be efficient and effective.
The airport is a transport service which is transport or moves a passenger activity (human) and cargo (goods) from airports of origin to destination by plane. Air infrastructure is the main supporter of the functions of the social system and the economic system in people's daily lives and is a physical asset that is designed to provide public services of the transportation services sector. Infrastructure needs (domestic and interisland) and improve linkages with the international community.

\section{METHODS}

Research variables used in determining the feasibility analysis are non-tax revenues (Revenues Non-tax) as a source of revenue to operate and maintain this activity. The financial aspects were is calculated using investment criteria include Net Present Value (NPV); BenefitCost Ratio (BCR); Internal Rate of Return (IRR) and Payback Period (PP).

\section{RESULT AND DISCUSSION \\ 4.1 Air Transport Growth Rate}

To predict the volume growth of air transport will use Syukuran Aminuddin Amir Airport until the age of projects implemented are the factors influencing that growth factors the number of aircraft that arrive and depart, the number of 
passengers who arrive and depart, the quantity of cargo unloaded and loaded, and the amount of luggage were unloaded and loaded. To that end, air transport growth predictions based on historical data, namely the existence of statistical data. Table 1 shows the statistical data growth of air transport in the last 10 years Syukuran Aminuddin Amir Airport (2009-2018).

Analysis of the rate of growth of air transport modeling using geometric models, exponential models, and arithmetic models more are presented in Table 2. The geometric growth model assumes that the same growth rate annually. The exponential growth model is directly continuous growth (continuous) which is influenced by several factors, for example in the calculation of their population growth as a result of factors influence birth and death. The arithmetic growth model provides projections of growth under the assumption that the amount of growth in the future will increase by the same amount each year, this model is used if only the amount of total growth he wants to know.

The results of the analysis predicted good growth of air transport aircraft, passengers, baggage and cargo in Syukuran Aminuddin Amir Airport in from 2019 up to the year 2038 using the geometric method can be seen in Table 3 .

Table 1. Growth of Air Transport Departing and Arriving The Syukuran Aminuddin Amir Airport

\begin{tabular}{ccccccccc}
\hline \multirow{2}{*}{ Year } & \multicolumn{2}{c}{ Plane } & \multicolumn{2}{c}{ Passenger } & \multicolumn{2}{c}{ Luggage $(\mathrm{kg})$} & \multicolumn{2}{c}{ Freight $(\mathrm{kg})$} \\
\cline { 2 - 8 } & Unloading & Loading & Unloading & Loading & Unloading & Loading & Unloading & Loading \\
\hline 2009 & 545 & 544 & 30157 & 31056 & 332473 & 291505 & 57163 & 85856 \\
2010 & 537 & 536 & 43466 & 44341 & 401814 & 202053 & 141146 & 558 \\
2011 & 1051 & 1051 & 52257 & 55148 & 483635 & 137654 & 199388 & - \\
2012 & 1158 & 1158 & 74787 & 73408 & 635470 & 252629 & 331433 & - \\
2013 & 1135 & 1134 & 76722 & 78244 & 638459 & 483185 & 368301 & - \\
2014 & 1627 & 1628 & 98936 & 95099 & 875544 & 740333 & 510375 & 262318 \\
2015 & 1877 & 1877 & 112594 & 119355 & 1018867 & 860310 & 712397 & 157541 \\
2016 & 2854 & 2859 & 166438 & 166291 & 1182101 & 1601366 & 235913 & 537796 \\
2017 & 2872 & 2870 & 173292 & 182417 & 1391411 & 1183682 & 447588 & 593203 \\
2018 & 3420 & 3421 & 198583 & 202538 & 1738313 & 1510085 & 562811 & 597100 \\
\hline
\end{tabular}


Table 2. Growth Model Air Transport Departing and Arriving The Syukuran Aminuddin Amir Airport

\begin{tabular}{ccccccc}
\hline & \multicolumn{5}{c}{ Air Transport Growth Model } \\
\cline { 2 - 6 } Description \\
\cline { 2 - 6 } Type Air & \multicolumn{2}{c}{ Geometric (\%) } & Exponential (\%) & Arithmetic (\%) \\
\cline { 2 - 6 } Transport & $\begin{array}{c}\text { Coming/ } \\
\text { Unloading }\end{array}$ & $\begin{array}{c}\text { Departing/ } \\
\text { Load }\end{array}$ & $\begin{array}{c}\text { Coming/ } \\
\text { Unloading }\end{array}$ & $\begin{array}{c}\text { Departing/ } \\
\text { Load }\end{array}$ & $\begin{array}{c}\text { Coming/ } \\
\text { Unloading }\end{array}$ & $\begin{array}{c}\text { Departing/ } \\
\text { Load }\end{array}$ \\
\hline Aircraft & 20.16 & 20.19 & 18.37 & 18.39 & 52.75 & 52.89 \\
Passenger & 20.74 & 20.62 & 18.85 & 18.75 & 55.85 & 55.22 \\
Luggage & 17.99 & 17.88 & 16.54 & 16.45 & 42.28 & 41.80 \\
Freight & 25.70 & 21.40 & 22.87 & 19.39 & 88.46 & 59.55 \\
\hline
\end{tabular}

Table 3. Predicted Air Transport

\begin{tabular}{|c|c|c|c|c|c|c|c|c|}
\hline \multirow{3}{*}{ Year } & \multicolumn{8}{|c|}{ Air Transport Type } \\
\hline & \multicolumn{2}{|c|}{ Plane } & \multicolumn{2}{|c|}{ Passenger } & \multicolumn{2}{|c|}{ Luggage (kg) } & \multicolumn{2}{|c|}{ Freight $(\mathrm{kg})$} \\
\hline & Unloading & Loading & Unloading & Loading & Unloading & Loading & Unloading & Loading \\
\hline 2017 & 2872 & 2870 & 173292 & 182417 & 1391411 & 1183682 & 447588 & 593203 \\
\hline 2018 & 3420 & 3421 & 198583 & 202538 & 1738313 & 1510085 & 562811 & 597100 \\
\hline \multicolumn{9}{|c|}{ Prediction Airport Start Year New } \\
\hline 2019 & 4110 & 4102 & 239771 & 244318 & 2050998 & 1780069 & 707436 & 724894 \\
\hline 2020 & 4818 & 4942 & 289900 & 294899 & 2419827 & 2098324 & 819236 & 880040 \\
\hline 2021 & 5934 & 5999 & 349549 & 355480 & 2855219 & 2475478 & 1117730 & 1068390 \\
\hline 2022 & 7130 & 7138 & 422050 & 438796 & 3368811 & 2915705 & 1404952 & 1297053 \\
\hline 2023 & 8567 & 8579 & 509588 & 517234 & 3974786 & 3416996 & 1865982 & 1574655 \\
\hline 2024 & 10294 & 10301 & 615282 & 623912 & 4609768 & 4051489 & 2219789 & 1910670 \\
\hline 2025 & 12370 & 12392 & 742899 & 752590 & 5533349 & 4715804 & 2790283 & 2320825 \\
\hline 2026 & 14864 & 14893 & 896985 & 907611 & 6128678 & 5629726 & 3507201 & 2817528 \\
\hline 2027 & 17860 & 17900 & 1081450 & 1095044 & 7701045 & 6616227 & 4406443 & 3420549 \\
\hline 2028 & 21463 & 21503 & 1307663 & 1320893 & 9088854 & 7822702 & 5541281 & 4125632 \\
\hline 2029 & 25788 & 25856 & 1578888 & 1583322 & 10723904 & 9211304 & 6965121 & 5041400 \\
\hline 2030 & 30987 & 30975 & 1906368 & 1921940 & 12661428 & 10868994 & 8355001 & 6120185 \\
\hline 2031 & 37234 & 37349 & 2301771 & 2318333 & 14928324 & 12813371 & 11004857 & 7430301 \\
\hline 2032 & 44743 & 44888 & 2719186 & 2796488 & 17611600 & 15504242 & 13832770 & 9020572 \\
\hline 2033 & 53360 & 53949 & 3315623 & 3473246 & 20781906 & 17804692 & 17381571 & 10951200 \\
\hline 2034 & 64606 & 54840 & 4051617 & 4068967 & 24520117 & 20987949 & 21855996 & 13295031 \\
\hline 2035 & 77624 & 77928 & 4891978 & 4908177 & 28930758 & 24740333 & 27471567 & 16140500 \\
\hline 2036 & 93274 & 93699 & 5906622 & 5930472 & 34134760 & 29563597 & 34530923 & 19194971 \\
\hline 2037 & 112079 & 112566 & 7131724 & 7141549 & 40274857 & 34377685 & 43404529 & 23768785 \\
\hline 2038 & 134674 & 135289 & 8670923 & 8684469 & 47529424 & 40529987 & 54557907 & 28880181 \\
\hline
\end{tabular}




\subsection{Revenue Cost Estimation Airport}

\subsubsection{Aeronautical revenue}

The estimated cost of revenue aeronautics Syukuran Aminuddin Amir Airport is based on rates set by the Government Regulation (PP) No. 15 of 2016 regarding Type and Tariff on NonTax Revenue in force at the National Institute of Aeronautics and Space the magnitude Rates Services Landing, Placement and Storage Aircraft (PJP4U), services tariff revenue from Passenger Aircraft services (PJP2U).

\subsubsection{Non-Aeronautical Revenues}

Cost of revenue non-aeronautical services warehouse is assumed to be as much as $20 \%$ of revenue aeronautics consisting of interest income from the rental of space and land, concessions, interest income from the use of electricity, water and telephone debtor (tenant), service installation of billboards, service usage lounge area domestic, revenue fitting/port, cargo handling.

\subsection{Construction Costs}

According to Aminuddin Amir Masterplan Thanksgiving Luwuk Airport, this airport will undergo expansion by increasing the length of the runway from 2250 meters to 3000 meters to be able to serve a larger aircraft type. Details of the Budget Plan can be seen in Table 4 .
Table 4. Estimated Construction Cost

\begin{tabular}{|c|c|c|}
\hline \multirow{2}{*}{ Type of Work } & \multicolumn{2}{|c|}{ Stages } \\
\hline & Phase I (IDR) & Phase II (IDR) \\
\hline $\begin{array}{l}\text { Preparatory } \\
\text { work }\end{array}$ & $1,150,190,580.00$ & $1,150,190,580.00$ \\
\hline Earthworks & $100,000,000,000.00$ & $100,000,000,000.00$ \\
\hline $\begin{array}{l}\text { Civil works } \\
\text { airside }\end{array}$ & $56,714,981,688.00$ & $70,843,659,591.00$ \\
\hline $\begin{array}{l}\text { Civil works } \\
\text { landside }\end{array}$ & - & $2,023,122,901.00$ \\
\hline $\begin{array}{l}\text { Drainage civil } \\
\text { works }\end{array}$ & - & $3,244,026,180.00$ \\
\hline Building work & $81,140,000,000.00$ & $101,092,300,000.00$ \\
\hline Total real cost & $239,005,172,268.00$ & $278,353,299,252.00$ \\
\hline $\begin{array}{l}\text { Contingencies } \\
(10 \%)\end{array}$ & $23,900,517,226.80$ & $27,835,329,925.20$ \\
\hline Number of 1 & $262,905,689,494.80$ & $306,188,629,177.20$ \\
\hline Vat $10 \%$ & $26,290,568,949.48$ & $30,618,862,917.72$ \\
\hline Total & $289,196,258,444.28$ & $336,807,492,094.92$ \\
\hline \multirow[t]{2}{*}{ Be rounded } & $289,196,258,000.00$ & $336,807,492,000.00$ \\
\hline & Grand Total & $626,003,750,000.00$ \\
\hline
\end{tabular}

\subsection{Investment Feasibility Analysis}

Investment feasibility analysis conducted with a view to evaluating the financial feasibility of the project. The method used is the Net Present Value (NPV), internal rate of return (IRR), and Profitability Index (PI), Payback Period (PP), Break-Even Point (BEP) and sensitivity analysis (SA). The amount of Net Present Value (NPV) is the assessment of the feasibility of investment is determined by using the calculation proceeds Present Value multiplied by the interest rate applicable to the parties who will give loans. Development Syukuran Aminuddin Amir Airport will be financed by the state budget Pure assuming a lowinterest rate of $15 \%$ per year. Thus the NPV is calculated as follows: 
Table 5. The amount of the Net Present Value 15\% Syukuran Aminuddin Amir Airport

\begin{tabular}{|c|c|c|c|}
\hline Year & $\begin{array}{l}\text { Proceed's } \\
\text { (IDR) }\end{array}$ & $\begin{array}{c}\text { DF } \\
(15 \%)\end{array}$ & $\begin{array}{c}\text { PV from } \\
\text { Proceed's (IDR) }\end{array}$ \\
\hline 2019 & $7,830,065$ & 0870 & $6,808,752$ \\
\hline 2020 & $9,916,676$ & 0756 & $7,498,432$ \\
\hline 2021 & $13,403,603$ & 0658 & $8,813,086$ \\
\hline 2022 & $18,043,646$ & 0572 & $10,316,513$ \\
\hline 2023 & $24,204,036$ & 0497 & $12,033,683$ \\
\hline 2024 & $32,366,098$ & 0432 & $13,992,758$ \\
\hline 2025 & $43,160,117$ & 0376 & $16,225,487$ \\
\hline 2026 & $57,410,117$ & 0327 & $18,767,668$ \\
\hline 2027 & $76,196,003$ & 0284 & $21,659,660$ \\
\hline 2028 & $100,924,345$ & 0247 & $24,946,954$ \\
\hline 2029 & $133,434,487$ & 0215 & $28,680,839$ \\
\hline 2030 & $176,125,557$ & 0187 & $32,919,126$ \\
\hline 2031 & $232,126,164$ & 0163 & $37,726,991$ \\
\hline 2032 & $305,514,196$ & 0141 & $43,177,911$ \\
\hline 2033 & $401,602,467$ & 0123 & $49,354,728$ \\
\hline 2034 & $527,309,909$ & 0107 & $56,350,852$ \\
\hline 2035 & $691,643,856$ & 0093 & $64,271,619$ \\
\hline 2036 & $906,326,617$ & 0081 & $73,235,830$ \\
\hline 2037 & $1,186,609,465$ & 0070 & $83,377,495$ \\
\hline 2038 & $1,552,330,058$ & 0061 & $94,847,800$ \\
\hline \multicolumn{3}{|c|}{ Total PV Cash Flow } & $705,006,183,592$ \\
\hline \multicolumn{3}{|c|}{ PV Investment } & $626,003,750,000$ \\
\hline \multicolumn{3}{|c|}{ Difference } & $79,002,433,592$ \\
\hline
\end{tabular}

With a discount factor of capital required by the owner of $15 \%$ of the proceeds proposal, which is greater than the present value of the expenditure Investment Development Syukuran Aminuddin Amir Airport, so the NPV is positive or IDR.79,002,433,592.00, then it can be said investment profitable or feasible.

The internal rate of return calculation is defined as the interest rate that will make the value of the proceeds is expected to be received (the PV of future proceeds) basically to be sought by means of "trial and error" with all-round attempts. Differences between the DF or the interest held a positive NPV with DF which produce negative cultivated exceeding $5 \%$ difference of greater than $5 \%$ more to contain the possibility of error compared to the $5 \%$ or smaller, so in this case, the author uses interest rate $15 \%$ as required by the investor and $30 \%$.

Table 6. The amount of the Net Present Value 15\% Syukuran Aminuddin Amir Airport

\begin{tabular}{rrrr}
\hline Year & $\begin{array}{c}\text { Proceed's } \\
\text { (IDR) }\end{array}$ & $\begin{array}{c}\text { DF } \\
(15 \%)\end{array}$ & $\begin{array}{c}\text { PV from } \\
\text { Proceed's (IDR) }\end{array}$ \\
\hline 2019 & $7,830,065$ & 0769 & $6,023,127$ \\
2020 & $9,916,676$ & 0592 & $5,867,855$ \\
2021 & $13,403,603$ & 0455 & $6,100,866$ \\
2022 & $18,043,646$ & 0350 & $6,317,582$ \\
2023 & $24,204,036$ & 0269 & $6,518,851$ \\
2024 & $32,366,098$ & 0207 & $6,705,486$ \\
2025 & $43,160,117$ & 0159 & $6,878,269$ \\
2026 & $57,410,117$ & 0123 & $7,037,951$ \\
2027 & $76,196,003$ & 0094 & $7,185,252$ \\
2028 & $100,924,345$ & 0073 & $7,320,865$ \\
2029 & $133,434,487$ & 0056 & $7,445,455$ \\
2030 & $176,125,557$ & 0043 & $7,559,658$ \\
2031 & $232,126,164$ & 0033 & $7,664,089$ \\
2032 & $305,514,196$ & 0025 & $7,759,334$ \\
2033 & $401,602,467$ & 0020 & $7,845,960$ \\
2034 & $527,309,909$ & 0015 & $7,924,508$ \\
2035 & $691,643,856$ & 0012 & $7,995,498$ \\
2036 & $906,326,617$ & 0009 & $8,059,431$ \\
2037 & $1,186,609,465$ & 0007 & $8,116,786$ \\
2038 & $1,552,330,058$ & 0005 & $8,168,024$ \\
\hline & Total PV Cash Flow & $144,494,847,191$ \\
& PV Investment & & $626,003,750,000$ \\
& Difference & & $(481,508,902,809)$ \\
\hline & & &
\end{tabular}


Based on the results of the internal rate of return calculation using Equation 4, then the IRR>DF or $36142 \%>15 \%$, it can be said Investment Development Syukuran Aminuddin Amir Airport feasible.

By the use of the two $\mathrm{B} / \mathrm{C}$ ratio obtained the value of $\mathrm{B} / \mathrm{C}$ Ratio $=1.126$. Therefore $\mathrm{B} / \mathrm{C}$ ratio $>1$, it can be said that the development of Syukuran Aminuddin Amir Airport feasible.

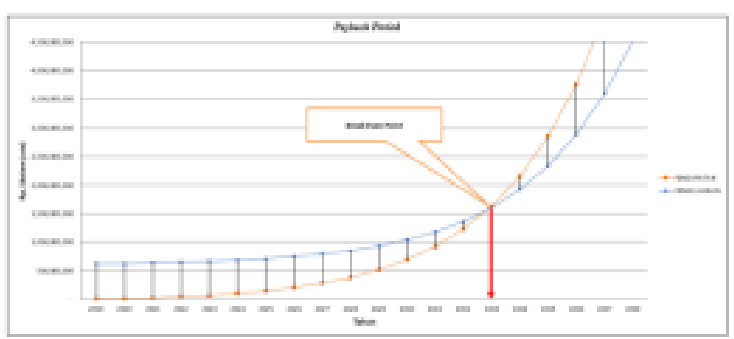

Figure 2. Break-Even Point (BEP) Investment Development Syukuran Aminuddin Amir Airport

From the analysis of Break-Even Point (BEP) Investment Development Syukuran Aminuddin Amir Airport Year 2019 to 2038 was in 2033 or occurred in the 15 th year.

\section{CONCLUSION}

From the results of investment appraisal using the Net Present Value (NPV), the obtained results of IDR.79.002.433.592.00, which means that the investment is feasible. Results of investment appraisal methods Internal Rate
Of Return (IRR), it can be seen that the IRR> DF which is equal to $36.142 \%$ of $>$ $15 \%$, it can be said that this investment is feasible. The result of the assessment B / C ratio is greater than 1 (one) or $\mathrm{PI}=1,126>$ 1. Calculation of Payback Period (PP) together with the results of the calculation of Break-Even Point (BEP) that is for 15 years, with an interest rate of $15 \%$ is still considered safe in terms of the initial cost. it can be concluded that the economic analysis, development of Syukuran Aminuddin Amir Airport is feasible and can cover investment and operating costs of the airport.

\section{REFERENCES}

Abubakar, I. (1997). Financing Jakarta's Mass Transit System. Proceeding of the Eastern Asia Society for Transportation Studies, 263-275.

Algaf, A.R., Mulyani, E., \& Rafi'e. (2017). Studi Kelayakan Bandara Udara Baru Kabupaten Ketapang. Prodi Teknik Sipil Fakultas Teknik UNTAN.

Antono, A.A. (2007). Studi Kelayakan Pembangkit Listrik Tenaga Mikrohidro studi kasus: PLTMH Kalibawang di Dusun Sorotanan Desa Banjararum Kecamatan Kalibawang Kabupaten Kulonprogo. Tugas Akhir, Universitas Gadjah Mada.

Arya, K.H. (2018). Analisis Kelayakan Investasi Navigasi Penerbangan Periode 2015 - 2017 (Studi Kasus Perum Lppnpi Distrik Yogyakarta). 
Bubalo, B., \& Daduna, J. R. (2010). Airport Capacity and Demand Calculations by Simulation - The Case of Berlin-Brandenburg International Airport. Berlin School of Economics and Law. German Airport Performance, Badensche Str. 50 - 51, D - 10825 Berlin.

Harta, H. (2013). Analisis Kelayakan Finansial Pembangunan Pabrik SGA (Smelter Grade Alumina) Mempawah Dengan Proses Bayer.

Herlianto, D., \& Pujiastuti, T. (2009). Studi Kelayakan Bisnis. Yogyakarta: Graha Ilmu.

Husnan, S., \& Muhammad, S. (2005). Studi Kelayakan Proyek Edisi 4. Yogyakarta: UPP AMP YKPN.

Jorge, J.D., \& Rus, G.D. (2004). CostBenefit Analysis of Investments in Airport Infrastructure. A Practical Approach Journal of Air Transport Management, 10, 311-326. DOI:10.1016/j.jairtraman.2004.05.00 1.

Kadariah. (2001). Evaluasi Proyek Analisis Ekonomi. Universitas Indonesia. Jakarta.

Leli, H.N.D. (2012). Analisis Ekonomi Dan Finansial Pengembangan Bandar Udara Internasional Minangkabau (BIM) di Sumatera Barat.

Mangitung, D.M. (2014). Ekonomi Rekayasa Disertai penyelesaian perhitungan dengan Spreadsheet. ISBN 978-979-29-3571-4.

Melisa, O., Maulid, M.I., \& Melawaty, A. (2017). Kelayakan Investasi Pengembangan Gedung Terminal Penumpang Bandar dara Internasional Sultan Mahmud Badaruddin II Palembang.
Moetriono, H., \& Suharno. (2012). Analisis Perpanjangan Landas Pacu (Runway) Dan Komparasi Biaya Tebal Perkerasan (Studi Kasus Pada Bandar Udara Abdulrachman Saleh Malang). Extrapolasi Jurnal Teknik Sipil Untag Surabaya, 5(1), 61- 79.

Muttaqin, A., Sartono, W., \& Christady, H. (2009). Analisis Geometrik Fasilitas Sisi Udara Bandar Udara Internasional Lombok (BIL) Nusa Tenggara Barat. In Proceeding Forum Teknik Sipil No. XIX/1Januari 2009.

Nadiasa, M., Maya.W.D.N.K., \& Norken I.N. (2010). Analisis Investasi Pengembangan Potensi Pariwisata Pada Pembangunan Waduk Jehem Di Kabupaten Bangli. Jurnal Ilmiah Teknik Sipil, 14(2).

Nurhayati, A., \& Dewi, R.K.S. (2017). Ekonomi Teknik. Bandung: Sekolah Tinggi Teknologi Bandung.

Oleng, A.P., Jansen, F., \& Manoppo, M. (2017). Perencanaan Pengembangan Bandar Udara Sultan Babulah Kota Ternate Provinsi Maluku Utara. Jurnal Sipil Statik, 5(6), 373-382.

Permana, S.J., \& Widyastuti, H. (2013). Studi Perencanaan Pengembangan Landas Pacu (Runway) Dan Landas Hubung (Taxiway) Bandara Abdulrachman Saleh Malang. Jurusan Teknik Sipil, Fakultas Teknik Sipil dan Perencanaan, Institut Teknologi Sepuluh Nopember (ITS). Jurnal Teknik Pomits, 1(1), 1-6.

Pemerintah Indonesia. (2016). Peraturan Pemerintah (PP) Nomor 15 tahun 2016 tentang Jenis dan Tarif atas Jenis Penerimaan Negara Bukan Pajak yang berlaku pada Lembaga Penerbangan dan Antariksa Nasional. 
Prihadi, T. (2010). Analisis Investasi Cetakan 1. Jakarta: Penerbit PPM.

Rizani, M. D. (2012). Studi kelayakan Ekonomi dalam pengembangan bandar udara, Studi kasus di bandar udara Internasional Minangkabau.

Rosmayantini, L., \& Dewi, P.R.P. (2015). Tinjauan Kelayakan Runway Untuk Pesawat Jenis B737 - 800 Yang Beroperasi Di Bandar Udara Djalaluddin Gorontalo Sekolah Tinggi Penerbangan Indonesia Curug, Tangerang. Jurnal Ilmiah Aviasi Langit Biru, 10(2).

Syahyunan. (2014). Studi Kelayakan Bisnis. Medan: USU Press. ISBN: 9794587559.

Tiwa, F., Walangitan, D.R.O., \& Mochtar, S.M. (2016). Evaluasi Kelayakan Proyek Berdasarkan Analisis Kriteria Investasi. Jurnal Sipil Statik, 4(9), 577-583.

Yinny, R., Harianto, H., \& Monty, G. (2006). Studi Kelayakan Ekonomi Pengembangan Bandara Udara Internasional Minangkabau (BIM). 